\title{
Fast generation of high producer cho cell lines by an iterative transfection process P-A Girod ${ }^{1,2}$, M Grandjean11, D Calabrese ${ }^{1,2}$, D Martinet ${ }^{3}$, J Beckmann ${ }^{3}$ and N Mermod*1
}

Address: ${ }^{1}$ Laboratory of Molecular Biotechnology, University of Lausanne, 1015 Lausanne Switzerland, ${ }^{2}$ Selexis SA, Geneva, Switzerland and ${ }^{3}$ Division of Genetics, Lausanne University Hospital (CHUV), Swtizerland

* Corresponding author

from The 4th Recombinant Protein Production Meeting: a comparative view on host physiology Barcelona, Spain. 2I-23 September 2006

Published: 10 October 2006

Microbial Cell Factories 2006, 5(Suppl I):S4I doi:10.I I86/I475-2859-5-SI-S4 I

(C) 2006 Girod et al; licensee BioMed Central Ltd.

\section{Background}

Isolation of mammalian cell clones for high-level protein production remains usually impeded by the time-consuming processes of selection, gene amplification and the analysis of many clones that is required to identify one with favorable properties, while maintaining proper protein properties and consistency. Expression variability results in part from the site of transgene integration in the host genome, and from the variable number of transgene copies that integrate. We and others have shown that genetic insulator elements such as MAR can be used to shield transgenes from inhibitory effects of the surrounding chromosomal sequences, alleviating in part integration site effects [1-4]. However, productivity remains limited by the number of transgenes that can be intergrated in the host genome. Thus, it would be useful to increase the number of integrated transgenes, and to render this integration process more frequent and more reproducible.

\section{Results}

In this presentation, we will describe a multiple transfection procedure that allows simple generation of cell lines with high and stable levels of recombinant protein production. We will show that this technique improves significantly transgene expression, up to 10 -fold in polyclonal population of $\mathrm{CHO}$ cells, and that this effect results in part from increased transgene integration. Using various combinations of vector elements, we show that improved transgene expression requires homologous DNA sequences in the successively transfected DNAs. Using FISH studies, we demonstrate that the DNAs integrate at a random, but unique, position within the cell genome, and that high productivity is achieved without chromosome rearrangement nor transgene amplification. Overall, our studies imply that homologous recombination mediates high efficiency integration of many transgene copies within the cellular genome. When this process is coupled to the use of chromatin control elements such as MARs, productivities of up to $80 \mathrm{picogram} / \mathrm{cell} / \mathrm{day}$ can be achieved when expressing IgGs.

\section{Conclusion}

Overall, these results indicate that mammalian cell clones displaying very high productivities can be obtained at a high frequency when using an efficient transfection process combined with effective vector elements.

\section{References}

I. Zahn-Zabal M, Kobr M, Imhof MO, Chatellard P, de Jesus M, Wurm $F$, Mermod N: Development of stable cell lines for production or regulated expression using matrix attachement regions. $J$ Biotechnol 2001, 87:29-42.

2. Girod PA, Mermod N: Use of Scaffold/Matrix-Attachment Regions for protein production. New Comprehensive Biochemistry, Gene transfer and expression in mammalian cells 2003, 38:359-379.

3. Girod PA, Zahn-Zabal M, Mermod N: Use of Matrix attachment regions to generate high producer cell lines. Biotechnol Bioeng 2005, 91 : I-II.

4. Girod PA, Nguyen D, Calabrese D, Grandjean M, Martinet D, Beckmann J, Bucher $\mathrm{P}$, Mermod $\mathrm{N}$ : In silico identification of potent 
Matrix attachment regions from genomes and use to generate high producer cell lines. Manuscript in preparation .

Publish with BioMed Central and every scientist can read your work free of charge

"BioMed Central will be the most significant development for disseminating the results of biomedical research in our lifetime. " Sir Paul Nurse, Cancer Research UK

Your research papers will be:

- available free of charge to the entire biomedical community

- peer reviewed and published immediately upon acceptance

- cited in PubMed and archived on PubMed Central

- yours - you keep the copyright

Submit your manuscript here:

http://www.biomedcentral.com/info/publishing_adv.asp 